http://kitaibelia.unideb.hu/

ISSN 2064-4507 (Online) • ISSN 1219-9672 (Print)

(C) Department of Botany, University of Debrecen, Hungary

23 (1): 31-38.; 2018

DOI: $10.17542 /$ kit.23.31

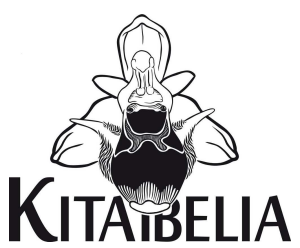

\title{
Lengyel és Hőgyész környéki Natura 2000 erdőterületek florisztikai adatai
}

\author{
VAS István \& TóTH István Zsolt \\ H-7191 Hőgyész, Jókai u. 9.; istvanvas00@yahoo.de \\ H-7150 Bonyhád, Kossuth L. u. 23.
}

\begin{abstract}
Floristic data from Lengyel-Hőgyész Natura 2000 site (SW Hungary)
Abstract - This paper presents occurrence data of 169 taxa from the Lengyel-Hőgyész Natura 2000 site (HUDD20026) which is on the southern part of Tolna Hills, SW Hungary. Data were collected during three years (2015, 2016, 2017), on different sites annually. The presented data contribute to the distribution dataset of Atlas florae Hungariae. Regionally rare or sporadic species (e.g. Asplenium scolopendrium, Asplenium trichomanes, Polystichum setiferum, Doronicum hungaricum, Paris quadrifolia, Scilla vindobonensis) are enumerated. Presence of Epipactis leptochila subsp. neglecta and Platanthera chlorantha were not registered from this site before. Subspecies of Carex divulsa are also studied on this site - distribution of these infraspecific taxa have not been mapped recently in Hungary.
\end{abstract}

Keywords: flora mapping, protected species, Tolna Hills, Transdanubia, vascular plants

Összefoglalás - Munkánkban 169 faj előfordulási adatait közöljük az eddig még egységesen nem vizsgált Lengyel-Hőgyészi-erdők (HUDD20026) Natura 2000 területéről, amely a szintén keveset vizsgált Tolnai-hegyhát déli részén terül el. A flóratérképezési munkában a terület három egymást követő évben (2015, 2016, 2017), különböző egységekben lett felmérve. A vizsgálat adatai kiegészítik Magyarország edényes növényfajainak elterjedési atlasza térképeit is. Kiemelhetők az országban vagy a Dél-Dunántúlon ritka, többségükben védett taxonok (pl. Asplenium scolopendrium, Asplenium trichomanes, Polystichum setiferum, Doronicum hungaricum, Paris quadrifolia, Scilla vindobonensis) mellett a területen korábban nem regisztrált Epipactis leptochila subsp. neglecta, a Platanthera chlorantha és a Carex divulsa országosan nem tisztázott elterjedésű alfajainak (subsp. divulsa és a subsp. leersii) előfordulása is.

Kulcsszavak: Dunántúl, flóratérképezés, hajtásos növények, Tolnai-hegyhát, védett fajok

\section{Bevezetés}

A Lengyel-Hőgyészi-erdők (HUDD20026) Natura 2000 területe a Tolnai-hegyhát déli részén terül el. A Tolnai-hegyhát a Nyugat-Balkáni flóratartományban (Illyricum), a Dél-Dunántúl flóravidéken (Praeillyricum) a Külső-Somogy flórajárás (Kaposense) kistája. Nyugatról a Kapos, északról és keletről a Sió képezi a természetes határokat, délen pedig a Völgység határolja (KEVEY 2004). Klímazonálisan északi része erdőssztyep, amit déli részén a zárt tölgyes öv vált fel. Vegetációja illír és pannon átmeneti jelleget mutat (Soó 1962). Területe völgyekkel és szurdokokkal sűrűn felszabdalt, magasra kiemelt és nagy reliefenergiájú. Ez a geomorfológiai tulajdonsága is megkülönbözteti a szomszédos Mezőföldtől (TELEKI 2012). A terület éghajlatában a szubmediterrán és a kontinentális hatások is érvényesülhetnek. Alapkőzete a pleisztocén lösz, amelyben helyenként durva homokrétegek vannak. A vastag lösztakaróval 
(20-40 m) fedett hegyhátak (tengerszint feletti átlagmagasságuk $220 \mathrm{~m}$ ) többnyire északnyugati-délkeleti irányúak, és felszínüket deráziós völgyek és fülkék sűrű hálózata tagolja. A lapos hegyhátak között széles és mély eróziós völgyek alakultak ki.

A vizsgált Natura 2000 különleges természetmegőrzési terület kiterjedése 3635,99 ha, északi része Hőgyész környékén és a Kapos-völgy keleti felén, a déli rész a Kurd-Lengyeli út mentén húzódik Lengyel falúig (1. ábra).

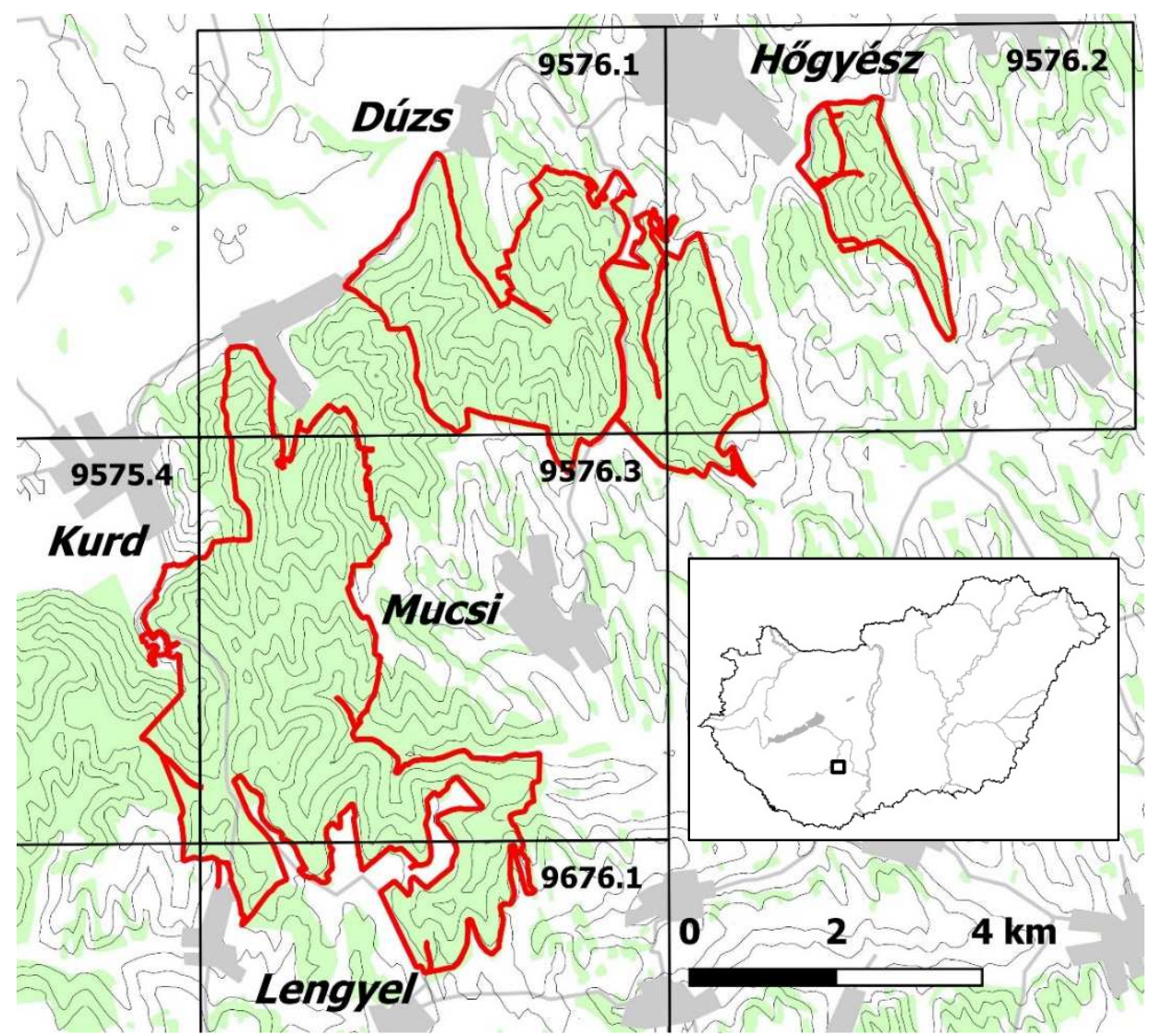

1. ábra. A Lengyel-Hőgyészi-erdők Natura 2000 terület (HUDD20026) és az érintett KEF kvadrátok

Fig. 1. The Lengyel-Hőgyész Natura 2000 site (HUDD20026) and the related CEU grid cells

A területen a fafajok 66,2\%-a cseres-kocsánytalan tölgyes (Potentillo micracanthaeQuercetum dalechampii), 32,7\%-a a gyertyános-tölgyes (Asperulo taurinae-Carpinetum) és 1,1\%-a a bükkös (Helleboro odori-Fagetum) asszociációkra jellemző faj. A bükkösök főként a déli, Völgységgel határos részen jelennek meg. A területen 85\%-ban kőzethatású és barna erdőtalajok találhatók (HoRVÁTH 2010, KISS 2017).

Adatgyưjtési munkánkat a Duna-Dráva Nemzeti Park megbízásából 2015-2017 közötti időszakban végeztük. A munka elsődleges célja adatok gyűjtése volt a körzet okszerü erdőtervezési munkájához. Az adatok hozzájárulnak az edényes növényfajok flóratérképi adatainak kiegészítéséhez is (BARTHA et al. 2015).

A vizsgált területről csak nagyon kevés korábbi adat áll rendelkezésünkre. Kis számban HoRVÁt $(1942 a, 1942 b)$ és Hollós $(1911,1915)$ közöltek adatokat. Később KEVEY (1993), KIRÁLY (2007) és TóTH $(2013,2014)$ kutattak még a területen. 


\section{Anyag és módszer}

Az első szerző 2015 és 2017 között összesen 85 terepnapon gyűjtött előfordulási adatokat a gyepszint fajaira vonatkozólag. Minden évben más erdészeti körzetben, a leginkább természetes, vagy természetközeli erdőtagokban ill. részletekben zajlott az adatgyűjtés. A ritka, védett fajokról fotódokumentáció készült.

Jelen tanulmányban csak azok a taxonok szerepelnek, amelyek ritkák, védettek, illetve a vizsgálat által érintett kvadrátokban nem jelzi előfordulásukat Magyarország edényes növényfajainak elterjedési atlasza (BARTHA et al. 2015). A felmérés a következő KEF (CEU) kódú kvadrátokra terjedt ki: 9576.1, 9576.2, 9576.3, 9575.4, 9676.1.

A dűlők, erdők megnevezése a Tolnai-hegyhát turistatérképén (1:25000) feltüntetett neveket, a taxonok sorszáma és nomenklatúrája az Új magyar füvészkönyvet (KIRÁLY 2011) követi. Egy-egy adat gyűjtésének évét a kvadrátazonosító melletti évszám jelzi.

\section{Enumeráció}

8. Equisetum telmateia Ehrh. - Lengyel: Fürdő-erdő [9676.1, 2017].

26. Polypodium vulgare L. - Dúzs: Égett-depó [9576.1, 2016], Kurd: Betyár-gödör [9576.3, 2017].

32.Asplenium scolopendrium L. - Lengyel: Fürdő-erdő [9676.1, 2017], Kurd: Betyár-gödör [9576.3, 2017].

37.Asplenium trichomanes L. - Dúzs: Dúzsi-erdő [9576.1, 2016], Kurd: Betyár-gödör [9576.3, 2017].

42.Athyrium filix-femina (L.) Roth - Kurd: Községi-erdő [9575.4, 2017], Lengyel: Fürdő-erdő [9676.1 2017].

50. Polystichum setiferum (Forssk.) Woyn. - Lengyel: Aranyási-gödör [9676.1, 2017].

51.Polystichum aculeatum (L.) Roth - Lengyel: Fürdő-erdő [9676.1, 2017].

55. Dryopteris filix-mas (L.) Schott - Lengyel: Fürdő-erdő [9676.1, 2017].

56. Dryopteris carthusiana (Vill.) H.P. Fuchs - Lengyel: Aranyási-gödör Fürdő-erdő [9676.1, 2017]. 149. Parietaria officinalis L. - Kurd: Községi-erdő [9575.4, 2017], Lengyel: Fürdő-erdő [9676.1, 2017].

157. Asarum europaeum L. - Hőgyész: Sózó [9576.2, 2015], Lengyel: Fürdő-erdő [9676.1, 2017].

165. Persicaria dubia (Stein) Fourr. - Dúzs: Égett depó [9576.1, 2016].

335. Lychnis coronaria (L.) Desr. - Lengyel: Fürdő-erdő [9676.1, 2017].

352. Silene noctiflora L. - Hőgyész: Malom-hegy [9576.2, 2016].

353. Silene nutans L. - Hőgyész: Malom-hegy [9576.2, 2016].

375. Dianthus armeria L. - Hőgyész: Szállás-puszta felett [9576.1, 2015], Kurd: Száraz-árok [9576.3, 2017], Lengyel: Kőris-völgy feletti út mellett [9676.1, 2017].

394. Isopyrum thalictroides L. - Hőgyész: Malom-hegy [9576.2, 2016].

395. Actaea spicata L. - Lengyel: Kőris-völgy [9676.1, 2017].

399. Aconitum vulparia Rchb. - Lengyel: Fürdő-erdő [9676.1, 2017].

408. Anemone ranunculoides L. - Hőgyész: Malom-hegy [9576.2, 2016].

412. Hepatica nobilis Schreb. - Kurd: Községi-erdő [9575.4, 2017], Lengyel: Magtermelo, Mucsi: Papdi-völgy, Uradalmi-erdő [9576.3, 2017], Lengyel: Fürdő-erdő, Aranyási-gödör [9676.1, 2017].

424. Adonis vernalis L. - Hőgyész: Malom-hegy [9576.2, 2016].

435. Ranunculus ficaria L. - Kurd: Községi-erdő [9575.4, 2017].

460. Thalictrum aquilegiifolium L. - Hőgyész: Malom-hegy [9576.2, 2016].

462. Thalictrum minus L. - Hőgyész: Roszkopf [9576.2, 2015].

485. Corydalis cava L. - Kurd: Községi erdő [9575.4, 2017]. 
487. Corydalis pumila Rchb. - Hőgyész: Cseffő Keszi-katlan [9576.1, 2015].

532. Cardamine impatiens L. - Hőgyész: Cseffő Keszi-katlan [9576.1, 2015], Dúzs: Dúzsierdő, Égett-depó [9576.1, 2016], Lengyel: Fürdő-erdő [9676.1, 2017].

542. Cardamine pratensis L. - Mucsi: Papdi-völgy [9576.3, 2017].

547. Arabis glabra (L.) Bernh. - Hőgyész: Szállás-puszta [9576.1, 2015]. -

567. Rorippa sylvestris (L.) Besser - Dúzs: Dúzsi-erdő [9576.1, 2017], Lengyel: Fürdő-erdő [9676.1, 2017].

835. Lembotropis nigricans (L.) Griseb. - Mucsi: Papdi-erdő [9576.3, 2017].

838. Chamaecytisus supinus (L.) Link - Hőgyész: Cseffő [9576.1, 2015], Hőgyész: Malomhegy $[9576.2,2016]$.

844. Chamaecytisus ratisbonensis (Schaeff.) Rothm. - Mucsi: Papdi-erdő [9576.3, 2017].

850. Genista ovata Waldst. et Kit. - Dúzs: Sipőcz [9576.1, 2016].

869. Astragalos glycyphyllos L. - Lengyel: Kőris-völgy [9576.1, 2017].

897. Vicia tenuifolia Roth. - Hőgyész: Malom-hegy [9576.2, 2016].

916. Lathyrus hirsutus L. - Mucsi: Papdi-erdő [9576.3, 2017].

963. Trifolium campestre Schreb. - Dúzs: Dúzsi-erdő [9576.1, 2016], Hőgyész: Malom-hegy [9576.2, 2016].

973. Trifolium alpestre L. - Hőgyész: Tildy-vadföld [9576.1, 2015].

1009. Geranium sanguineum L. - Hőgyész: Malom-hegy [9576.2, 2016].

1052. Euphorbia epithymoides L. - Hőgyész: Tildy-vadföld [9576.1, 2015], Dúzs: Dúzsi-erdő

[9576.1, 2016], Hőgyész: Malom-hegy [9576.2, 2016].

1057. Euphorbia amygdaloides L. - Hőgyész: Malom-hegy, Cseffő Sózó [9576.2, 2016].

1070. Dictamnus albus L. - Kurd: Iván-árok feletti erdőrész [9576.3, 2017].

1121. Lavatera thuringiaca L. - Lengyel: Fürdő-erdő [9676.1, 2017].

1134. Daphne mezereum L. - Lengyel: Fürdő-erdő, Aranyási-gödör [9676.1, 2017].

1145. Hypericum hirsutum L. - Hőgyész: Cseffő, Dúzs: Dúzsi-erdő [9576.1, 2015], Lengyel: Fürdő-erdő, Kőris-völgy [9676.1 2017].

1154. Viola suavis M. Bieb. - Hőgyész: Cseffő Keszi-katlan felett, Dúzs: Dúzsi-erdő [9576.1, 2016], Kurd: Községi-erdő [9575.4, 2017].

1162. Viola riviniana Rchb. - Lengyel: Magtermelő [9576.3, 2017].

1204. Circaea lutetiana L. - Lengyel: Fürdő-erdő, Kőris-völgy [9676.1, 2017].

1241. Sanicula europaea L. - Hőgyész: Cseffő Keszi-katlan, Dúzs: Dúzsi-erdő, Sipőcz [9576.1,

2016], Lengyel: Fürdő-erdő, Kőris-völgy [9676.1, 2017].

1250. Chaerophyllum temulum L. - Lengyel: Fürdő-erdő [9676.1, 2017].

1262. Aegopodium podagraria L. - Lengyel: Fürdő-erdő, Kőris-völgy [9676.1, 2017].

1277. Aethusa cynapium L. - Hőgyész: Szénégető keleti oldalán [9576.1, 2015].

1314. Peucedanum cervaria (L.) Lapeyr. - Hőgyész: Tildy-vadföld, Cseffő Fősorompói út [9576.1, 2015], Hőgyész: Malom-hegy Csirkeláb, Rontott diós [9576.2, 2016].

1325. Torilis japonica (Houtt.) DC. - Hőgyész: Cseffő Keszi-katlan, Langental [9576.1, 2015], Lengyel: Fürdő-erdő [9676.1, 2017].

1354. Lysimachia nummularia L. - Lengyel: Fürdő-erdő [9676.1, 2017].

1357. Lysimachia punctata L. - Hőgyész: Cseffő Fősorompói út [9576.1, 2017], Kurd: Sáncitető alatti völgy [9576.3, 2017].

1412. Lithospermum officinale L. - Lengyel: Kőris-völgy [9576.1, 2017].

1418. Cerinthe minor L. - Hőgyész: Tildy-vadföld [9576.1, 2015], Dúzs: Dúzsi-erdő [9576.1, 2016].

1424. Pulmonaria officinalis L. - Lengyel: Fürdő-erdő, Kőris-völgy, Aranyási-gödör [9676.1, 2017].

1429. Symphytum tuberosum L. - Hőgyész: Malom-hegy Rontott diós [9576.2, 2016], Lengyel: Fürdő-erdő, Kőris-völgy [9676.1, 2017].

1446. Myosotis sylvatica (Ehrh.) Hoffm. - Hőgyész: Cseffő Keszi-katlan [9576.1, 2015].

1449. Myosotis sparsiflora J.G. Mikan - Dúzs: Dúzsi-erdő [9576.1, 2016]. 
1450. Myosotis arvensis subsp. umbrata (Rony.) O.Schwarz. - Dúzs: Dúzsi-erdő [9576.1, 2016].

1459. Cynoglossum officinale L. - Hőgyész: Szállás-pusztai Langental nyugati oldalán [9576.1, 2015], Dúzs: Dúzsi-erdő [9576.1, 2016].

1472. Ajuga reptans L. - Kurdi és a lengyeli erdőtagokban mindenhol gyakori [9576.3, 2017].

1473. Ajuga genevensis L. - Hőgyész: Tildy-vadföld [9576.1, 2015], Dúzs: Sipőcz Mucsi-tető [9576.1, 2016], Hőgyész: Malom-hegy Lindental [9576.2, 2016], Kurd: Községi-erdő, Sáncitető, Mucsi-Papdi-erdő [9576.3, 2017].

1482. Scutellaria altissima L. - Hőgyész: Malom-hegy [9576.2, 2016], Kurd: Sánci-tető alatti völgy, Mucsi: Papdi-erdő [9576.3, 2017].

1486. Sideritis montana L. - Hőgyész: Szállás-pusztai Langental nyugati oldalán [9576.1, 2015].

1487. Melittis melissophyllum L. - Hőgyész: Malom-hegy Lindental [9576.2, 2016], Dúzs: Dúzsi-erdő, Sipőcz [9576.1, 2016], Lengyel: Fürdő-erdő, Kőris-völgy [9676.1, 2017].

1492. Galeopsis pubescens Besser - Lengyel: Fürdő-erdő, Kőris-völgy [9676.1, 2017].

1493. Galeopsis speciosa Mill. - Lengyel: Aranyási-gödör [9676.1, 2017].

1501. Galeobdolon montanum Pers. ex Rchb. - Lengyel: mindenhol gyakori [9676.1, 2017].

1509. Stachys recta L. - Hőgyész: Malom-hegy Csirkeláb [9576.2, 2016].

1510. Stachys sylvatica L. - Hőgyész: Malom-hegy [9576.2, 2016], Lengyel: mindenhol előfordul [9676.1, 2017].

1513. Stachys germanica L. - Dúzs: Sipőcz [9576.1, 2016].

1519. Glechoma hirsuta Waldst. et Kit. - Lengyel: mindenhol előfordul [9676.1, 2017].

1528. Calamintha menthifolia Host - Lengyel: Fürdő-erdő, Kőris-völgy [9676.1, 2017].

1530. Clinopodium vulgare L. - Lengyel: Kőris-völgy [9576.1, 2017].

1541. Lycopus europaeus L. - Lengyel: Fürdő-erdő, Kőris-völgy [9676.1, 2017].

1556. Salvia verticillata L. - Hőgyész: Tildy-vadföld [9576.1, 2015].

1557. Salvia glutinosa L. - Lengyel: Kőris-völgy, Aranyási-gödör [9676.1, 2017].

1569. Atropa belladonna L. - Lengyel: Fürdő-erdő, Aranyási-gödör [9676.1, 2017].

1595. Verbascum phoeniceum L. - Dúzs: Dúzsi-erdő [9576.1, 2016].

1596. Verbascum chaixii Vill. subsp. austriacum (Schott) Hayek - Hőgyész: Cseffő [9576.1, 2015].

1608. Scrophularia nodosa L. - Hőgyész: Szállás-puszta Dúzs: Sipőcz [9576.1, 2016], Lengyel: Fürdő-erdő, Aranyási-gödör [9676.1, 2017].

1641. Veronica chamaedrys L. s.str. - Dúzs: Dúzsi-erdő, Mucsi-tető [9576.1, 2016].

1665. Melampyrum nemorosum L. - Lengyel: Fürdő-erdő [9676.1, 2017].

1726. Galium odoratum (L.) Scop. - Hőgyész: Szállás-puszta, Cseffő [9576.1, 2015], Dúzs: Dúzsi-erdő [9576.1, 2016].

1741. Galium sylvaticum L. - Lengyel: Fürdő-erdő [9676.1, 2017].

1748. Cruciata laevipes Opiz. - Hőgyész: Szállás-puszta, Tildy-vadföld [9576.1, 2015].

1775. Valerianella locusta (L.) Laterr. - Hőgyész: Cseffő Keszi-katlan [9576.1, 2015].

1785. Dipsacus pilosus L. - Kurd: Sánci-tető alatti völgy [9576.3, 2017].

1791. Knautia drymeia Heuff. - Hőgyész: Cseffő Sózó [9576.2, 2015], Lengyel: Fürdő-erdő, Aranyási-gödör [9676.1, 2017].

1797. Campanula glomerata L. - Hőgyész: Malom-hegy [9576.2, 2016], Dúzs: Dúzsi-erdő [9576.1, 2016].

1801. Campanula bononiensis L. - Hőgyész: Cseffő Sózó [9576.2, 2015], Hőgyész: Malomhegy [9576.2, 2016].

1804. Campanula trachelium L. - Hőgyész: Cseffő, Dúzs: Dúzsi-erdő [9576.1, 2015, 2016], Lengyel: Fürdő-erdő [9676.1, 2017].

1807. Campanula patula L. - Hőgyész: Malom-hegy Rontott diós [9576.2, 2016], Lengyel: Fürdő-erdő, Kőris-völgy [9676.1, 2017].

1817. Eupatorium cannabinum L. - Lengyel: Fürdő-erdő, Kőris-völgy, Aranyási-gödör [9676.1, 2017]. 
1854. Inula britannica L. - Hőgyész: Cseffő Keszi-katlan [9576.1, 2015].

1862. Carpesium cernuum L. - Hőgyész: Roszkopf [9576.2, 2015], Kurd: Betyár-gödör, Mucsi: Papdi-völgy [9576.3, 2017].

1866. Bidens cernua L. - Hőgyész: Forrás-völgy [9576.1, 2015], Mucsi: Papdi-erdő, Uradalmierdő $[9576.3,2017]$.

1885. Galinsoga ciliata (Raf.) S.F. Blake - Hőgyész: Forrás-völgy [9576.1, 2015].

1933. Petasites hybridus (L.) G. Gaertn., B. Mey. et Scherb. - Lengyel: Fürdő-erdő [9676.1, 2017], Mucsi: Papdi-erdő [9576.3, 2017].

1935. Doronicum hungaricum (Sadler) Rchb. - Hőgyész: Malom-hegy Csirkeláb [9576.2, 2016], Kurd: Sánci-tető nyugati lejtője [9576.3, 2017].

1951. Senecio erraticus Bertol. - Mucsi: Uradalmi-erdő [9576.3, 2017].

1957. Senecio doria Nath. - Mucsi: Uradalmi-erdő [9576.3, 2017].

1982. Cirsium boujartii (Piller et Mitterp.) Sch.Bip. - Hőgyész: Roszkopf [9576.2, 2015].

1993. Serratula tinctoria L. - Hőgyész: Tildy-vadföld [9576.1, 2015].

2046. Mycelis muralis (L.) Dumort. - Dumart. Lengyel: mindenhol gyakori [9676.1, 2017].

2053. Lapsana communis L. - Hőgyész: Szállás-puszta, Cseffö [9576.1, 2015], Dúzs: Dúzsierdő $[9576.1,2015]$.

2079. Hieracium lachenalii C.C. Gmel. - Kurd: Földvár-hegy [9576.3, 2017].

2082. Hieracium sabaudum L. - Hőgyész: Cseffő Fősorompói út [9576.1, 2017], Hőgyész: Cseffő Sózó [9576.2, 2015], Kurd: Földvár-hegy [9576.3, 2017], Lengyel: Fürdő-erdő [9676.1, 2017].

2083. Hieracium racemosum Waldst. et Kit. - Hőgyész: Cseffő Fősorompói út, Dúzs: Dúzsierdő [9576.1, 2015], Hőgyész: Malom-hegy Lindental, Murgaispitz [9576.2, 2016], Hőgyész: Cseffő Sózó [9576.2, 2015], Kurd: Földvár-hegy, Mucsi: Papdi-erdő [9576.3, 2017], Lengyel: Kőris-völgy [9676.1, 2017].

2149. Colchicum autumnale L. - Mucsi: Uradalmi-erdő alatti rét [9576.3, 2017].

2153. Ornithogalum boucheanum (Kunth) Asch. - Hőgyész: Szénégető [9576.1, 2017].

2159. Ornithogalum umbellatum s.l. - Hőgyész: Szállás-puszta, Szénégető [9576.1, 2015, 2017], Dúzs: Dúzsi-erdő [9576.1, 2016], Hőgyész: Malom-hegy Lindental [9576.2, 2016].

2163. Scilla vindobonensis Speta - Mucsi: Uradalmi-erdő [9576.3, 2017], Kurd: Szent-kúti forrás [9575.4, 2017].

2169. Muscari neglectum Guss. ex Ten. - Hőgyész: Malom-hegy Lindental [9576.2, 2016], Kurd: Községi-erdő [9575.4, 2017].

2170. Muscari botryoides (L.) Mill. - Hőgyész: Cseffő Fősorompói út [9576.1, 2015], Hőgyész: Malom-hegy Lindental [9576.2, 2016], Kurd: Községi-erdő [9575.4, 2017].

2171. Allium vineale L. - Hőgyész: Langental [9576.1, 2015].

2172. Allium sphaerocephalon L. - Hőgyész: Forrás-völgy [9576.1, 2015], Hőgyész: Malomhegy $[9576.2,2016]$.

2174. Allium scorodoprasum L. - Hőgyész: Malom-hegy [9576.2, 2016].

2175. Allium rotundum L. - Hőgyész: Langental [9576.1, 2015].

2188. Allium oleraceum L. - Hőgyész: Malom-hegy, Murgaispitz [9576.2, 2016].

2192. Convallaria majalis L. - Dúzs: Dúzsi-erdő, Mucsi-tető [9576.1, 2016], Hőgyész: Cseffő Sózó, Malom-hegy Lindental [9576.2, 2016].

2195. Polygonatum latifolium (Jacq.) Desf. - Mucsi: Uradalmi-erdő, Kurd: Sánci-tető alatti völgy [9576.3, 2017], Lengyel: Fürdő-erdő [9676.1,2017].

2196. Polygonatum odoratum (Mill.) Druce - Kurd: Sánci-tető alatti völgy, Mucsi: Papdierdő, Uradalmi-erdő [9576.3, 2017], Lengyel: Fürdő-erdő, Aranyási-gödör [9676.1, 2017].

2197. Polygonatum multiflorum (L.) All. - Dúzs: Dúzsi-erdő, Sipőcz [9576.1, 2016], Hőgyész: Cseffő Sózó, Malom-hegy [9576.2, 2016], Lengyel: Fürdő-erdő, Aranyási-gödör [9676.1, 2017]. 
2199. Paris quadrifolia L. - Lengyel: Fürdő-erdő [9676.1, 2017].

2200. Ruscus acuelatus L. - Hőgyész: Malom-hegy [9576.2, 2016], Lengyel: Fürdő-erdő, Köris-völgy [9676.1, 2017].

2201. Ruscus hypoglossum L. - Lengyel: Fürdő-erdő, 34-es erdőtag, 15 tő [9676.1, 2017].

2222. Gagea pratensis (Pers.) Dumort. - Hőgyész: Malom-hegy [9576.2, 2016].

2223. Gagea lutea (L.) Ker Gawl. - Lengyel: Kőris-völgy [9576.1, 2017].

2235. Lilium martagon L. - Lengyel: Fürdő-erdő, Kőris-völgy [9676.1, 2017].

2246. Tamus communis L. - Lengyel: Fürdő-erdő [9676.1, 2017], Kurd: Községi-erdő [9575.4, 2017].

2252. Iris graminea L. - Hőgyész: Malom-hegy [9576.2, 2016].

2260. Iris variegata L. - Lengyel: Fürdő-erdő [9676.1, 2017], Hőgyész: Tildy-vadföld [9576.1, 2015].

2270. Juncus effusus L. - Hőgyész: Forrás-völgy [9576.1, 2015], Dúzs: Dúzsi-erdő [9576.1, 2016] .

2296. Festuca gigantea (L.) Vill. - Hőgyész: Szénégető [9576.1, 2015].

2358. Melica uniflora L. - Hőgyész: Malom-hegy [9576.2, 2016].

2384. Bromus benekenii (Lange) Trimen - Hőgyész: Tildy-vadföld, Cseffő [9576.1, 2015].

2389. Brachypodium sylvaticum (Huds.) P. Beauv. - Lengyel: Aranyási-gödör [9676.1, 2017].

2393. Elymus caninus (L.) L. - Hőgyész: Szénégető [9576.1, 2015].

2396. Elymus hispidus (Opiz) Melderis - Hőgyész: Szénégető [9576.1, 2015].

2471. Milium effusum L. - Hőgyész: Cseffő Keszi-katlan [9576.1, 2015].

2526. Arum maculatum L. - Kurd: Községi-erdő [9576.3, 2017].

2591. Carex remota L. - Lengyel: Fürdő-erdő [9676.1, 2017].

2598.1. Carex divulsa Stokes subsp. divulsa - Hőgyész: Tildy-vadföld, Cseffő [9576.1, 2015], Hőgyész: Malom-hegy [9576.2, 2016], Dúzs: Dúzsi-erdő, Mucsi-tető [9576.1, 2016], Kurd: Községi-erdő [9575.4, 2017], Kurd: Földvár-hegy, Sánci-tető, Mucsi: Papdi-erdő [9576.3, 2017], Lengyel: Fürdő-erdő [9676.1, 2017].

2598.2. Carex divulsa Stokes subsp. leersii (Kneucker) W.Koch - Dúzs: Dúzsi-erdő [9576.1, 2016], Hőgyész: Malom-hegy Murgaispitz [9576.2, 2016], Kurd: Földvár-hegy, Mucsi: Papdierdő [9576.3, 2017], Kurd: Vaskanyar [9575.4, 2017], Lengyel: Fürdő-erdő [9676.1, 2017].

2623. Carex digitata L. - Hőgyész: Szállás-puszta [9576.1, 2015], Mucsi: Uradalmi-erdő [9576.3, 2017], Lengyel: Fürdő-erdő [9676.1, 2017].

2631. Carex pendula Huds. - Lengyel: Fürdő-erdő, Kőris-völgy [9676.1, 2017].

2635. Carex pilosa Scop. - Lengyel: Fürdő-erdő, Kőris-völgy, Aranyási-gödör [9676.1, 2017].

2647. Carex michelii Host. - Hőgyész: Szállás-puszta [9576.1, 2015].

2659. Epipactis microphylla (Ehrh.) Sw. - Kurd: Községi -erdő, Iván-árok, Sánci-tető [9576.3, 2017], Kurd: Községi-erdő, Vaskanyar [9575.4, 2017].

2660.1. Epipactis leptochila (Godfery) Godfery. subsp. leptochila - Hőgyész: Cseffő Keszikatlan, Dúzs: Dúzsi-erdő, Sipőcz [9576.1, 2016], Hőgyész: Malom-hegy Csirkeláb [9576.2, 2016], Lengyel: Fürdő-erdő, Kőris-völgy [9676.1, 2017].

2660.2. Epipactis leptochila (Godfery) Godfery. subsp. neglecta (Kümpel) Kümpel. - Dúzs: Dúzsi-erdő, Mucsi-tető, Sipőcz [9576.1, 2016], Lengyel: Kőris-völgy [9676.1, 2017], Mucsi: Uradalmi-erdő [9576.3, 2017].

2666. Epipactis tallosii A. Molnár et Robatsch - Hőgyész: Rőzsés alatt a Donát-patak völgyében [9576.2, 2017].

2673. Epipactis helleborine (L.) Crantz - Kurd: Községi-erdő, Sánci-tető, Mucsi: Papdi-erdő [9576.3, 2017], Lengyel: Aranyási-gödör [9676.1, 2017].

2674. Epipactis purpurata Sm. - Lengyel: Magtermelő, Mucsi: Papdi-erdő [9576.3, 2017]. -

2675. Cephalanthera rubra (L.) Rich. - Kurd: Községi-erdő [9575.4, 2017], Kurd: Iván-árok [9576.3, 2017], Lengyel: Kőris-völgy [9676.1, 2017]. 
2676. Cephalanthera damasonium (Mill.) Druce - Hőgyész: Cseffő Keszi-katlan, Dúzs: Dúzsierdő, Mucsi-tető, Sipőcz [9576.1, 2016], Hőgyész: Malom-hegy [9576.2, 2016], Kurd: Földvár-hegy, Községi-erdő, Mucsi: Papdi-erdő [9576.3, 2017].

2677. Cephalanthera longifolia (L.) Fritsch - Hőgyész: Tildy-vadföld, Dúzs: Mucsi-tető [9576.1, 2016], Hőgyész: Malom-hegy Csirkeláb [9576.2, 2016], Kurd: Földvár-hegy, Sáncitető, Mucsi: Papdi-erdő [9576.3, 2017], Kurd: Községi-erdő [9575.4, 2017], Lengyel: Fürdőerdő, Aranyási-gödör [9676.1, 2017].

2678. Limodorum abortivum (L.) Sw. - Hőgyész: Cseffő [9576.1, 2015], Dúzs: Dúzsi-erdő [9576.1, 2016], Hőgyész: Malom-hegy Lindental [9576.2, 2016].

2680. Neottia nidus-avis (L.) Rich. - Dúzs: Mucsi-tető, Sipőcz [9576.1, 2016], Hőgyész: Malom-hegy [9576.2, 2017], Kurd: Községi-erdő [9575.4, 2017], Kurd: Sánci-tető, Mucsi: Papdi-erdő [9576.3, 2017], Lengyel: Fürdő-erdő, Aranyási-gödör [9676.1, 2017].

2686. Platanthera bifolia (L.) Rchb. - Hőgyész: Malom-hegy, Murgaispitz [9576.2, 2016], Kurd: Sánci-tető, Mucsi: Papdi-erdő [9576.3, 2017], Lengyel: Fürdő-erdő, Kőris-völgy [9676.1, 2017].

2687. Platanthera chlorantha (Custer) Rchb. - Hőgyész: Malom-hegy Csirkeláb [9576.2, 2016]. 2704. Orchis purpurea Huds. - Hőgyész: Tildy-vadföld, Farkas-árok [9576.1, 2017], Dúzs: Dúzsi-erdő, Mucsi-tető, Sipőcz [9576.1, 2016], Hőgyész: Malom-hegy, Rontott diós, Lindental, Murgaispitz [9576.2, 2016], Mucsi: Papdi-erdő [9576.3, 2017].

\section{Köszönetnyilvánítás}

Köszönjük Csábi Miklósnak a Epipactis leptochila subsp. neglecta azonosításában való közremúködését és a DDNP Igazgatóság, valamint a Hőgyészi Erdészet munkatársainak támogatását is.

\section{Irodalom}

Bartha D., Király G., Schmidt D., Tiborcz V., Barina Z., Csiky J., Jakab G., Lesku B., SchmotZer A., Vidéki R., Vојтко́ A. \& ZóLYoмi Sz. (szerk.) (2015): Magyarország edényes növényfajainak elterjedési atlasza. Nyugat-magyarországi Egyetem Kiadó, Sopron.

HoLLós L. (1911): Tolna vármegye flórájához. - Botanikai Közlöny 10: 89-108.

HoLLós L. (1915): Tolna vármegye flórájához. - Magyar Botanikai Lapok 13: 50-60.

HoRvÁt A. O. (1942a): Külsősomogy és környékének növényzete. - Borbásia 4 (6): 1-70.

Horvát A. O. (1942b): A Mecsekhegység és déli síkjának növényzete. - Ciszterci Rend, Pécs.

HoRváth L. (2010): Hőgyészi erdészeti tervezési körzet második erdôterve. - Baranya Megyei Mezőgazdasági Szakigazgatási Hivatal Erdészeti igazgatósága. Kézirat.

KEvEY B. (1993): Adatok Magyarország flórájának és vegetációjának ismeretéhez VI. - Botanikai Közlemények 80: 53-61.

KEvEy B. (2004): Dél-Dunántúl fokozottan védett növényei. - Kitaibelia 9: 67-83.

KIRÁLY G. (szerk.) (2009): Új magyar füvészkönyv. Magyarország hajtásos növényei. Határozókulcsok. Aggteleki Nemzeti Park Igazgatóság, Jósvafő.

KIRÁLY G. (2007): Kiegészítések Külső-Somogy edényes flórájának ismeretéhez. - Somogyi Múzeumok Közleményei 17: 31-40.

KISs G. (2017): Kapos-hegyháti Natúrpark natúrparki megalapozó szakmai háttértanulmány. - Dombóvár Ökológiai Lapja (www.kondavolgy.hu)

Soó R. (1962): Növényföldrajz. - Tankönyvkiadó, Budapest.

TEleKI B. (2012): Növényföldrajzi adatok a Völgység és a Tolnai-hegyhát keleti felére jellemző klímazonális vegetáció meghatározásához. - Tájökológiai Lapok 10: 25-40.

Tótн I.Zs. (2013): Botanikai adatok Tolnából, Baranyából. - Kitaibelia 18: 161-168.

TóTH I.Zs. (2014): Botanikai adatok Tolnából és Baranyából II. - Kitaibelia 19: 243-253. 